\title{
Vietnamese Revolutionaries and the Early Spread of Communism to Peninsular Southeast Asia:
}

\section{Towards a Regional Perspective}

\author{
CHRISTOPHER E. GOSCHA
}

\section{Abstract}

This paper adopts a regional and geographical approach to show how the early spread of communism to mainland Southeast Asia owes much to overseas Chinese and overland Vietnamese patterns of immigration. This wider approach seeks to get beyond the frontiers of nationalist histories and the formation of the 'modern' nation-state (whether colonial or national) in order to think in more material terms about how communism not entirely unlike Catholicism or any other religion first entered mainland Southeast Asia on the ground, by which channels, by which groups of people and at which times. The idea is to begin mapping out the introduction and spread of communism in peninsular Southeast Asia in both time and space. This, in turn, provides us with a methodologically and historically sounder basis for thinking about the 'why' of this Sino-Vietnamese revolutionary graft and the failure of this brand of communism to take hold in certain places and among certain peoples outside of China and Vietnam. 
Christopher E. Goscha

\section{Introduction}

It is well known that in the 17 th century French missionaries established their Asian religious headquarters and seminary in Ayuthia in a bid to spread Catholicism eastwards to Vietnam and China. It is also now known that when it came to converting the various Buddhist kingdoms of the peninsula to Christianity, the results were anything but successful, whether among the masses down below or the kings ruling them from on high. ${ }^{1}$ What is less known is that the early Asian intermediaries for the diffusion of Catholicism on the ground in the Buddhist kingdoms of Laos, Cambodia, Thailand and often in the ethnically diverse highlands were Vietnamese émigrés (known widely today as Viet kieu). Joining them were Japanese Christian refugees and overseas Chinese immigrants (Hua qiao), concentrated mainly in the ports of the South Seas (Nanyang) englobing much of what we call 'Southeast Asia' today. ${ }^{2}$ Compared to the Vietnamese, there were very few ethnic Lao, Khmer or Thai converts to or missionaries of Catholicism. ${ }^{3}$

Over two centuries later, Western-derived communism, like Catholicism, would also enter the Buddhist lands of Cambodia and Laos through Vietnamese channels, and not via the ethnic Lao and Khmer majority populations. In the Kingdom of Thailand, the introduction of radicalism would be shared by Chinese and Vietnamese communists working for the Comintern, the former relying on long-standing overseas Chinese communities in the port of Bangkok to spread the message, the latter preferring overland Vietnamese immigration routes running across Laos to upper northeast Thailand. Working together, in 1930 Chinese and Vietnamese internationalists led by Ho Chi Minh himself presided over formation of the Siamese and Malaya Communist Parties and a 'Laotian communist cell'. In the late 1940s, as the Chinese communist victory in China began to re-link Vietnamese communists to the world communist movement with which they had lost touch since the late 1930s, Vietnamese communists resurrected their prewar inter- 
nationalist contract by creating separate Laotian and Cambodian revolutionary parties as part of a larger 'Indochinese revolution', the 'front line' of revolution in Southeast Asia.

My aim in this paper is not to compare Vietnamese Catholics and communists, whether inside or outside Vietnam. Although a provocative parallel, it is also a very misleading one. ${ }^{4}$ Nor am I suggesting that to be 'communist' or 'Catholic' in Asia, one had to be 'Confucian' or 'Sinicized'. This would be misleading, as the success of Christianity in the Philippines shows, the Indonesian and Indian Communist Parties demonstrate, and the terrible excesses of Cambodian radicalism have made painfully clear. Moreover, Western and Japanese colonialism was the major catalytic force pushing many Asian anticolonialists to choose communism as a way of liberating their nations.

If I evoke the intermediary role Vietnamese immigrants played in the early propagation (truyen $b a$ ) of Catholicism and communism into the peninsula, my idea is simply to try to shift us into the regional currents of Vietnamese history and to get us thinking in less political and polemical terms and in more geographical and cultural ones about how Vietnamese internationalists became-together with the Chinese-the major agents for the introduction and early spread of communism into peninsular Southeast Asia prior to the Second World War, the subject of this reflection. ${ }^{5}$ For if much has been written on the 'grafting' (ghép cây) of (international) Marxism-Leninism to the (national) 'stock' (thân gôc) of Vietnamese patriotism, ${ }^{6}$ much less attention has been paid to how fervent Vietnamese internationalists served as the Asian intermediaries in the early spread of communism to Thailand, Laos and Cambodia between 1925 and 1954. ' What interests me therefore is the analytical value of a 'regional approach' extending over a longer span of time, ${ }^{8}$ one that allows us to get beyond the frontiers of nationalist histories and the formation of the 'modern' étatnation (whether colonial or national) in order to think in more geographical and material terms about how communism-not entirely unlike Catholicism-first entered mainland Southeast Asia on the ground: by which channels, through which groups of people and at what times. 
Christopher E. Goscha

What I cannot consider here is the flipside of this question-that is, the why: Why did Vietnamese (and Chinese) apparently feel more at ease propagating communism into the ethnically and culturally diverse lands of peninsular Southeast Asia at the outset? Or why did communism have such a hard time recruiting non-Chinese and Vietnamese revolutionaries to the internationalist cause in Malaya, Laos, Cambodia and Thailand before the Second World War? Knowing how the communist message was first evangelized, in which languages or how it was indigenized or rejected by the local populations would undoubtedly throw new light on such matters.

While I evoke some of these socio-cultural factors in my conclusion, because of space limitations I concentrate in this paper on how Vietnamese revolutionaries became the leading Asian intermediaries for spreading communism into parts of the peninsula located just west of the Annamese Cordillera (Truong Son), my shorthand for the contemporary states of Laos, Cambodia, Thailand and Malaysia. My idea is to begin mapping out the introduction and spread of communism in peninsular Southeast Asia along the geographical and material lines mentioned above. This will provide, I hope, a methodologically and historically sounder basis for a second, more socio-cultural essay on the why.

In both cases, though, I think it is important to extend our analysis over a longer span of time than we are normally accustomed to do. For the how, it might even be worthwhile to return as far back as the so-called 'precolonial period' in order to consider how ancient patterns of Sino-Vietnamese immigration across the Indochinese peninsula just may have combined to inscribe the early introduction of communism to peninsular Southeast Asia and to the western half of French Indochina in particular. Paradoxically, if official historiography in Hanoi today plays up the 'reality' of the 'special relationships' (quan he dac biet) binding revolutionary Vietnam to Laos and Cambodia, Vietnamese communists have conveniently forgotten that at the outset peninsular communism was a very Sino-Vietnamese affair ... 


\section{Nanyang: Between Southern China and Southeast Asia}

\section{Overseas Chinese and Overland Vietnamese Immigration into the Nanyang}

Long before the 20th century, the nature of Chinese immigration to Southeast Asian port and coastal cities had always provided Chinese political refugees with bases from which they sought shelter, collected funds, regrouped and tried, when possible, to overthrow the ruling power on the mainland. Many of these political refugees stayed on to make important historical contributions to local states. ${ }^{9}$ In Vietnam today, if the term Minh Huong is widely used to describe children of SinoVietnamese unions, it originally referred to southern Chinese émigrés who had remained 'loyal' (huong) to the overthrown Ming dynasty (Minh). On the run, the famous Mac family played a notable role in the economic, political and cultural development of the Ha Tien region, long before the ethnic Vietnamese got there. Similar things can be said for the Chinese in Thailand. ${ }^{10}$ 'Triad Societies' and 'Heaven and Earth Associations' (Thien Dia Hoi) originally seeking to restore the Ming emerged from the 17th century in Taiwan and throughout most of the Nanyang. In the 19th century, these associations spread eastwards as more and more Chinese immigrants went to Hawaii and the American West coast. Even the Vietnamese King Tu Duc would turn to these secret societies for help as the French consolidated their hold on southern Vietnam. ${ }^{11}$

Later, following his expulsion from Japan in 1907, Sun Yatsen would continue in this tradition by setting up branches of the Tongmenhui (TMH) among the Hua qiao living and working throughout Nanyang port cities, especially in Singapore, Malaya and Vietnam and often by winning over pre-existing secret societies. ${ }^{12}$ This link in ancient Chinese immigration between political dislocation in southern Chinese provinces and increased immigration to Southeast Asian port cities on the one hand and how it affected Southeast Asian states on the other is 
worth keeping in mind for revolutionary movements in the Nanyang into the 20th century. ${ }^{13}$

Vietnamese immigration to Southeast Asia never matched these Chinese movements, neither in numbers, economic success, nor in geographical reach. Indeed, if one can truly speak of 'overseas' (hai duong) for the Chinese, in the case of 'pre-colonial' Vietnam it is perhaps more accurate to speak of overland or coastal/river/immigration, movements that were much more peninsular in their scope. Two major routes in particular linked the ancient Vietnamese Kingdoms of Tonkin (Dang Ngoai) and Cochinchina (Dang Trong) to western parts of the peninsula. ${ }^{34}$ An overland one had connected Cochinchina to Lao and Thai kingdoms since at least the 17th century, if not long before. Connecting the markets of Vinh and Nakhon Phanom, this trail shuttled goods, animals, people, tribute and no doubt a few ideas across the Annamese range. It was also one of the few land routes between the more Sinicized world of Tonkin and the more Indianized and Buddhist kingdoms lying across the Ai-Lao Pass. Because of war, famine, religious persecution or better economic opportunities in the Mekong region, several thousand Vietnamese were living in villages in upper northeast Thailand by the late 19th century. Many more joined them following the French military occupation of central and northern Vietnam. However, this land trail to the Mekong was largely a Vietnamese one; given that Chinese immigration remained largely maritime and therefore concentrated in Thai coastal and port cities. ${ }^{15}$

To the south, coastal and Cambodian river routes had long brought Cochinchinese traders, settlers and Christians into Cambodia and Thailand, where Vietnamese quarters (ban in Thai) already existed in the 17th century. These movements in the Gulf of Thailand were probably facilitated by the larger movements of the Chinese and their regional junk trade between Canton and Ayuthia. Vietnamese Catholic fishermen, in particular, continued settling along the coast of the Gulf of Thailand-in Chantaboun, Trat, the Bangkok area and even further north along central Thailand's canals. By the early part of the 20th century, there were between 20 and 30,000 Viet kieu 
living in Thailand, concentrated in two major zones: 1) along the waterways stretching from the Gulf of Thailand inwards up the Chaophraya to Paknampho and Ban Dong and 2) in the present, upper northeastern Thai provinces of Sakhon Nakhon, Nakhon Phanom and Udon Thani, not far from the Vietnamese provinces of Nghe An and Ha Tinh (see Map). There were hardly any Lao, Khmer or Thai going abroad to study Catholicism in Macao, Penang or Rome. ${ }^{16}$

\section{Chinese and Vietnamese Revolutionary Immigration along Traditional Lines}

Knowing the geography of these overseas Chinese and overland Vietnamese colonies in Southeast Asia is helpful, for once the French colonized Indochina, Vietnamese anticolonialists turned to these overseas communities for shelter, funds and external bases for retaking Vietnam from the outside, with Gia Long's reliance on southeastern Thailand in the 18th century cited as a model to follow by early anticolonialists. This was even more the case for Prince Cuong De, a direct descendant of Gia Long opposed to the French, and Phan Boi Chau, another patriotic Vietnamese hero. ${ }^{17}$ Together, these two ran the famous Dong $D u$ (Voyage to the East) movement in Japan to train students in military arts and study Western modernization via a successful Asian importer. They were not alone: so too did Indian, Thai, Korean and Chinese nationalists, above all Sun Yat-sen whom Chau first met in Japan. Of course, Tokyo's expulsion of Phan Boi Chau's Dong Du movement in 1909 represented a major setback for Vietnamese anticolonialists, as it did for Sun. However, it simultaneously forced Phan Boi Chau to look to southern China and Thailand, in what would become a recurring strategic choice for Vietnamese circulating on the outside of Indochina over the next four decades. ${ }^{18}$

Given the troubled state of southern Chinese politics at the time, Phan Boi Chau moved the bulk of the Dong Du's students to Thailand, thanks to the tacit support of the Thai court, the chance to set up another 'quarter' near Ban Dong in central Thailand and the large Viet kieu populations there. As in the past, the direct descendant of Gia Long, Prince Cuong De, 
turned to the Thai court when it came to getting his family's throne back. But Phan Boi Chau may have chosen Thailand for three other reasons. First, he probably wanted to exploit his TMH regional contacts and Sun Yat-sen's shift to the Nanyang Chinese since early 1906, when Sun had created TMH branches in Singapore, Penang and Kuala Lumpur. In 1908, a General Bureau in Singapore came to life in charge of all the Nanyang branches. ${ }^{19}$ Second, Singapore was a key point in the TMH's arms trafficking in the Nanyang. Chau and his lieutenants went to Singapore to meet ranking TMH leaders (Chen Shunan) and Chinese arms dealers in 1908-09. Third, impressed by the bases and financial donations afforded to the TMH by the Hua qiao, Phan Boi Chau must have at least dreamed of doing the same in Thailand via the Viet kieu. He certainly cited overseas Hindu and Korean patriotic immigrant organizations in Asia as models for the Viet kieu to follow in Thailand. ${ }^{20}$

Nevertheless, compared to Sun Yat-sen, Phan Boi Chau's success rate was much more limited. With the French in control of western Indochina, Chau only had the Viet kieu in Thailand at his potential disposal. Moreover, the Vietnamese in Thailand could hardly match the donations of much richer Chinese in the Nanyang. And often they wanted nothing to do with 'revolution', happy to integrate peacefully into Thai society or remain faithful to their Christian traditions (see below). The large Vietnamese populations could, however, provide shelter close to Vietnam yet safe from direct French repression. With a blind eye from Thai authorities keen on one day getting parts of western Indochina back, Dong Du disciples set up revolutionary organizations in the Bangkok-Ayuthia area, in Phichit province and eventually in the Mekong provinces of Nakhon Phanom, Nong Khai and Udon Thani. Following Sun Yat-sen's victory in southern China in 1911 and formation of the Guomindang (GMD), Vietnamese revolutionaries would once again shift their headquarters back to the north, to Canton, but always kept in touch with their Thai operations.

What is important for our purposes here is that by the early 1920s, the inheritors of the Dong Du movement had established themselves firmly among the Vietnamese in upper northeast 
Thailand, ${ }^{21}$ just out of the direct reach of the French Sûreté, but connected to central Vietnam by the overland route described above. Anticolonialists led by Dang Thuc Hua made Udon Thani their headquarters rather than Ban Dong, reflecting a notable shift in the Vietnamese revolutionary movement from its former maritime tack to this overland route linking upper northeast Thailand to central Vietnam by way of Laos. If Phan Boi Chau had smuggled a couple of hundred young Vietnamese to Japan by way of the port of Hong Kong, one of the major routes for sending students to southern China now ran from central Vietnam to Udon Thani, Ban Dong and then on to Bangkok and Canton. Yet older ties remained intact: Phan Boi Chau's son-in-law was the main guide for bringing students out of Vietnam to the Mekong.

This change in tack in the Vietnamese revolutionary organization in Asia is important, for it helps to explain why some of the most important Vietnamese communists started their revolutionary training in northeast Thailand before moving on to the Youth League, the Whampoa Military Academy, the Comintern or the Chinese Communist Party (CCP) in southern China. I am thinking of Pham Hong Thai, Le Hong Phong, Le Hong Son, Hoang Van Hoan and General Hoang Sam. Vietnamese youngsters who followed this upper Indochinese route rarely went to France. This is also an important distinction, because a number of these Asian-trained Vietnamese militants would play the key role in forming a Cambodian and above all a Laotian revolutionary party after the Second World War (see below). ${ }^{2}$

But let us remain in 1925 for the moment, for the work of these early anticolonialists and their organizational presence among the Viet kieu in upper northeast Thailand in particular helps us to understand a little better how Western-derived radicalism would first flow from Canton into Thailand and Laos via these overseas Chinese and overland Vietnamese channels. This occurred between 1927 and 1930, when political trouble broke out in southern China and the Comintern began to promote an internationalist line, calling for communist parties in all of Asia to promote proletarian revolution. 
Christopher E. Goscha

\section{The Sino-Vietnamese Nature of Early Nanyang Communism}

\section{The Comintern and Converging Sino-Vietnamese Revolutionary Movements}

If Western-derived Catholicism arrived in force in East Asia via the maritime routes opened by the Portuguese in the 16th century, ${ }^{23}$ Soviet-backed communism made its strongest appearance by way of China-southern China, above all the ports of Canton and Shanghai. ${ }^{24}$ After all, the CCP had been formed in Shanghai in 1921 and the GMD's power-base had long been a southern Chinese-Nanyang affair. The triple entente between the GMD, the CCP and the Soviets therefore greatly enhanced the importance of Canton and Shanghai as key Asian revolutionary ports from 1924-25. It was thus not entirely an accident that Nguyen Ai Quoc (the future Ho Chi Minh) arrived in Canton from Moscow in late 1924 to work for the Soviet colonel Borodin and to form the famous Vietnamese Revolutionary Youth League around a year later. And he was not the only Asian communist landing there or working for Borodin.

Yet Ho was not of the Dong Du school. When he left Vietnam in 1911, he had first travelled to the West via the Suez Canal. In France, he took a reformist shot at the Ecole Coloniale. Rejected, he converted to communism, convinced that it was the only way left to win back Vietnam's independence. By making this choice, however, Quoc also entered an international revolutionary movement parallel to the colonial one he had just left that sent him back to Asia by way of Moscow and began to link his embryonic revolutionary movement to a larger communist world led by the Soviet Union. Again, he was not the only Asian making such a choice. Many Chinese students in France were making similar decisions: Li Lisan became head of the CCP in Shanghai after living in France and Chen Yannian formed the French branch of the CCP before returning to Canton in early 1925 (where he was also allegedly on good terms with Borodin). The formation of Quoc's Canton mission must 
therefore be placed in the wider context of the Comintern's China policy, the complex regional alliance between the CCP and the GMD at this time in Canton ${ }^{\text {s }}$, long-standing SinoVietnamese anticolonial contacts throughout the Nanyang, and the possibility of another level of French revolutionary connections linking Nguyen Ai Quoc to Chinese communists, many of whom also returned to southern China around 1925 by way of Moscow, such as Zhou Enlai and Chen Yannian.

Canton also offered Nguyen Ai Quoc the chance to graft his Youth League on to the Dong Du's revolutionary networks already running between southern China and northeast Thailand and to take advantage of increased Vietnamese immigration into southern China via French concessions and the Yunnan railway. ${ }^{x}$ In fact, Quoc was not quite a total stranger to the Dong $D u$ 's Asian organizations, thanks to family ties and long-standing friendships linking Viet kieu families in Canton and northeastern Thailand to his natal province in upper central Vietnam (via his sister for example). Relying on the prestige of Dang Thuc Hua among the Vietnamese in northeastern Thailand and Ho Hoc Lam among the Viet kieu and GMD circles in Canton, Quoc was able to take over the best of the Dong Du's bases and family connections in favour of the Youth League. ${ }^{27}$

On that note, combining the southern Chinese provinces of Yunnan, Guangxi and Guangdong and the Dong Du routes and bases in the Nanyang into a wider regional analysis of Vietnamese revolutionary activities might shed some new light on why Chinese and Vietnamese revolutionary movements were already intersecting in Canton when Nguyen Ai Quoc arrived there. ${ }^{28}$ Viewed from this regional angle, the strong revolutionary overlap between Nguyen Ai Quoc's Youth League and the GMD's Whampoa Military Academy (Truong Quan-Chinh Hoang Pho) in Canton is perhaps easier to grasp. After all, more than 300 Vietnamese youths were trained in Canton between 1925 and 1927, as students in the Whampoa Military Academy, members of the CCP and/or founders of the Vietnamese Youth League. Most of these young Vietnamese came from central and northern Vietnam, northeast Thailand, but rarely from Cochinchina. ${ }^{29}$ Besides hearing lectures from Nguyen Ai Quoc and 
Colonel Borodin, these budding Vietnamese revolutionaries also listened to ranking CCP leaders such as Zhou Enlai, Liu Shaoqi, Li Fuchan, Chen Yannian and Peng Pai. Even Nguyen Ai Quoc 'participated in' and 'executed loyally the orders' of the CCP between 1924 and 1927. And when Quoc was arrested in China in 1942 by the GMD, he was on his way to meet Zhou Enlai. ${ }^{30}$

The best example of this southern Chinese revolutionary intersection in Vietnamese communism is to be found in a recently rehabilitated Vietnamese communist general named Nguyen Son. Introduced into Chinese revolutionary circles by Ho Chi Minh in 1925, Son joined the CCP and fought in the Canton Uprising in 1927. In 1934, he became a member of the CCP's Central Committee and actually made the Long March with Mao Zedong's troops. By the late 1930s, he had become a high-ranking officer in the Red Army and was counted among the CCP's political elite. Back in Vietnam in 1945, Nguyen Son took command of central Vietnamese fighting forces (LKIV), together with two other Vietnamese officers who had been trained in Chinese military schools, namely Generals Le Thiet Hung and Nguyen Binh. In 1948, Ho Chi Minh personally honoured Nguyen Son (in Chinese characters) as the 'talented general of two countries'. Indeed, he was. ${ }^{31}$

If I digress briefly here, my point is to underscore the importance of not letting recent problems in Sino-Vietnamese relations and modern Asian boundaries blind us to the regional, transnational character of early Vietnamese communism and its movement within these southern Chinese channels, themselves a reflection of the southern tilt of Chinese communism. This is especially the case as we return to Southeast Asia/Nanyang along Sino-Vietnamese routes. For if southern China was the CCP's and Youth League's main base at this point, changes in southern Chinese politics were-as always-going to make themselves felt in the Nanyang. More than anything else, the violent break between the GMD and the CCP in April 1927 and the violence triggered by the failed Canton Uprising at the end of that year sent thousands of Chinese (mainly Hainanese) fleeing on junks and steamers to the Nanyang countries ${ }^{*}$, where 
many communist refugees began forming new and/or breakaway CCP branches in opposition to the GMD's older organizations. In Singapore, Chinese radicals transformed the South Seas [Nanyang] Branch Committee of the CCP into the South Seas [Nanyang] Communist Party (SSCP), whose First Congress took place in 1927. Directed by CCP headquarters now in Shanghai, the SSCP was given permission 'to gradually expand its activities to all parts of the South Seas'. ${ }^{33}$ It was in this context that CCP members either pushed out of southern China or now in opposition to the GMD in the Nanyang region tried to form entirely independent CCP branches in Saigon and Bangkok in 1927 and 1928. What attracted them most was tapping into the pre-existing Hua qiao communities and especially the growing Chinese working classes concentrated in these urban centres. However, the success of Chinese communists in Saigon in the late 1920s was less than impressive, owing to the long-standing GMD presence there and tight European surveillance. It was only in September 1938, as the Sino-Japanese war expanded into southern China, that a CCP 'section' appeared in southern Vietnam. ${ }^{34}$

Nguyen Ai Quoc was obviously aware of this Chinese exodus towards Southeast Asia from 1927, since he was smuggling his own students out of Canton and on to safe bases in northeast Thailand. Caught directly in the cross-fire of Chinese civil war, on 5 May 1927, Quoc left Canton for Shanghai, Hong Kong, and then on to Vladivostock, where a member of the French Communist Party (FCP) suggested that he eventually return to Thailand via Paris to rebuild the Vietnamese movement. Quoc agreed and returned to Moscow. In November 1927, on instructions from the Comintern, he left for Paris. There, French communists helped him finalize his plans to rebuild the revolutionary movement in Indochina through the formation of an external base in Thailand. ${ }^{35}$ As for southern China, the Youth League was in shambles, as several competing, non-communist Vietnamese émigré groups gained increased GMD backing in southern China against the communists. ${ }^{36}$

Coinciding with this shift from southern China to the Nanyang by Chinese and Vietnamese communists was the inter- 
nationalization of the Asian communist movement by the Comintern. In May 1928, the 6th Congress of the Comintern was convened. With the GMD's attack on the CCP as well as internal political concerns in mind, Stalin ordered communists in colonial areas to abandon their alliances with bourgeois nationalist parties in favour of international proletarian revolution. The French claim that during his trip to Moscow, Quoc was instructed by the Executive Central Committee of the 3rd International to form a communist party for Indochina.$^{37}$ Before building a party, though, Comintern leaders had first to reevaluate the state of their remaining Asian bases following the GMD's crackdown. It did not take them long to understand that Quoc would have to begin his work on Indochina's western flank, in northeast Thailand.

Reinforcing Quoc's trip to Thailand was the presence among the Viet kieu in Thailand of a handful of his most trusted collaborators, trained by him in Canton and sent to Thailand following the Canton violence (Hoang Van Hoan comes to mind). Quoc arrived in Bangkok sometime in mid-1928. He then hurried to Ban Dong in Phichit province, the very one created by Phan Boi Chau's lieutenants. There, in an overseas Chinese shop, Quoc met with one of his most trusted students (also an in-law of Dang Thuc Hua). He then moved on to the main base in Udon Thani. During this time, he trained Vietnamese sent from Vietnam, transferred from Canton and recruited from among the Viet kieu. With Dang Thuc Hua's backing, Quoc took over the Dong Du's bases in Thailand by converting most of the Dang family to his revolutionary project and carefully keeping them in charge of the Thai bases. He went out of his way to win over the Viet kieu to the patriotic cause; for they were his stepping-stones leading back into Vietnam. In 1928, Quoc transferred his Youth League to Thailand by forming the Provincial Committee of Udon Thani (Tinh Uy U-Don). In December 1929, he returned to Hong Kong to preside over the formation of a unified communist party in January or February 1930 (the date still remains unclear). Given the effectiveness of French repression inside Indochina, the geography of Comintern liaisons in southern China and thanks to 
help from the CCP itself, the Vietnamese Communist Party (VCP, Dang Cong San Viet Nam) was established in Hong Kong, highlighting the larger Asian context into which Vietnamese communism was born and the French repressive machine that kept it there.

But what interests me most here is what Nguyen Ai Quoc did following the unification of the $\mathrm{VCP}^{38}$ renamed in late 1930 the Indochinese Communist Party (ICP) on Comintern instructions. For during his trip to southern China, Quoc met with Western Comintern chiefs such as Hilaire Noulens and was named the chief of the Far Eastern Bureau (FEB), which was eventually relocated to Hong Kong too. Quoc was charged with building communism in all the Nanyang region-honed down by the Comintern to include French Indochina, Thailand, the Dutch Indies, British Malaya and Burma, and probably the Philippines. To this end, he returned to Hong Kong to form a suboffice of the FEB, to be known aptly as the Southern Bureau. This body may also have been home to the CCP's headquarters for administering the southern Chinese provinces of Yunnan, Guangxi and Guangdong, highlighting again the degree to which revolutionary jurisdiction for southern China and the Nanyang region continued to overlap into the 1930s. ${ }^{39}$

The FEB had to be run by Asians familiar with the region, its languages and geography. While Quoc was not necessarily Moscow's first choice, ${ }^{40}$ he was particularly well suited for the Comintern's Nanyang job. He had the language skills, the major Asian contacts of the Dong Du and Youth League, the leading patriotic émigré leaders in northeastern Siam (Dang Thuc Hua) and even in southern China (Ho Hoc Lam). ${ }^{41} \mathrm{He}$ was also known within the CCP and FCP. Nguyen Ai Quoc's instructions were clear: he was to place the Vietnamese Communist Party under the direction of the Comintern's Singapore office; transform the South Seas [Nanyang] Communist Party into the Malaya Communist Party; attach the Nanyang's Central Committee in charge of South Seas' communist movements to the Singapore Section of the Comintern; and to create a Siamese Communist Party by combining Chinese communists attached to the Nanyang branch in Bangkok with their Vietnamese Youth 
League counterparts in the northeast. These decisions were in line with Comintern directives calling for a party in each regional state, whether colonial or not. ${ }^{42}$

Quoc disagreed with the Comintern's desire to attach the Vietnamese party to the SSCP Secretariat based in Singapore. ${ }^{43}$ He argued that Vietnam's proximity to China made it wiser to place the Vietnamese organization under the FEB in southern China, together with communist parties from China, Japan and Korea. ${ }^{44}$ Geographically, Quoc explained, Vietnam was more closely linked to southern China, given the long-standing maritime and land links connecting the two countries. In a letter to the Comintern, dated 18 February 1930, he stressed that northern Vietnam was propitiously positioned at the tip of a revolutionary thrust extending southwards from Russia across China to Tonkin. ${ }^{45}$

However, even if Quoc inclined towards southern China for building Vietnamese communism (with the CCP's and Comintern's presence in Shanghai and Hong Kong firmly in mind ${ }^{46}$ ), the Nanyang nature of his internationalist tasks ensured that his movements would have to be linked to Singapore. For this reason, Quoc was quick to add, 'I ask the Chinese C[ommunist] $P$ [arty] [for] a letter of introduction so that we may send an Annamese comrade to work with Singapore. ${ }^{47}$ Given the level of Sino-Vietnamese co-operation in Canton, Quoc counted on the CCP's overseas organizations to execute the Comintern's directives in Southeast Asia. Some time in March 1930 he returned to Bangkok for the second time. He met with overseas Chinese communists first before moving inwards to Viet kieu strongholds in northeastern Thailand. ${ }^{48}$

\section{The Sino-Vietnamese Origins of Thai Radicalism}

Quoc transformed the Youth League's Udon Provincial Committee into the Northeastern Siamese Territorial Committee (Xu Uy Dong Bac Xiem). ${ }^{49}$ He explained to his followers the international situation; the recent creation of the VCP in Hong Kong; and relayed the Comintern's desire to establish a Siamese Communist Party. He made it clear that the Comintern had issued instructions calling for the participation on the part of all 
cadres in the proletarian revolution in whichever Asian state they might reside, regardless of ethnic distinctions. For this reason, he insisted, Vietnamese radicals in Thailand now had the responsibility of helping the Thai 'masses' to create a revolution in the 'spirit of international proletarianism'. Quoc called on his men to select appropriate members from the Youth League section to become communists and to foster the establishment of the 'Siamese' party, separate from the VCP. In another meeting, Quoc explained that Thailand was still a feudal country and a semi-colony. It had not reached the stage of a socialist revolution. It first had to pass through a democratic period and then, with the help of the international communist movement, it would reach the stage of a socialist revolution. Vietnamese militants in Thailand now had to reorient their attention towards the Thai as part of a world revolution..$^{50}$

To my knowledge, this was the first time since the 17 th century that Vietnamese immigrants living in Thailand had been asked to try to convert the non-Vietnamese majority to a universalistic Western ideology. In fact, Nguyen Ai Quoc's trip to Thailand in 1930 on behalf of the Comintern marked the beginning of Vietnamese communist efforts to use their Viet kieu patriotic networks to introduce and to spread communism to an ethnically non-Viet country. It coincided with a similar reorientation in the CCP's Nanyang organizations, especially in Malaya, where the internationalist line still coming from Shanghai continued to dominate until Mao Zedong's Long March reoriented Chinese communism inwards towards Yanan and $\mathrm{Li}$ Lisan returned to Moscow.

In April 1930, back in Bangkok, Nguyen Ai Quoc joined with CCP cadres of the South Seas Communist Party (see above) to form the Siamese Communist Party (SCP, Dang Cong San Xiem in Vietnamese). Vietnamese and Chinese ran its Central Committee, including Quoc's Canton students Le Manh Trinh and Tran To Chan. Fu Ta Chang, a Chinese member of the CCP's Southern Bureau, helped Quoc jump-start Siamese radicalism, ${ }^{51}$ for at the outset the SCP was a remarkably un-Thai affair and a very Sino-Vietnamese import. Of the SCP's 325 party members, most were Chinese industrial and estate workers who were said 
to be 'of weak quality', unable to carry out their tasks effectively. Ethnically, there were 55 Vietnamese and 20 Cantonese. The rest were Hainanese. ${ }^{52}$ This is hardly surprising given the Comintern's proletarian line and the large Chinese working class in Bangkok. In the northeast, where there was no real working class other than a very small number of overseas Chinese and Vietnamese coolies and construction workers, the SCP was run by Vietnamese from Viet kieu communities. 'As for authentic Siamese comrades', Hoang Van Hoan tells us, 'there weren't that many' (dong chi thuc su la nguoi Xiem thi khong co may). The best recruits in the northeast, he claims, came from the offspring of Thai-Viet mixed marriages. ${ }^{53}$ Revealingly, Hoan says he spent most of his time translating Chinese revolutionary tracts. Or as a November 1932 article in a Party paper summed up the SCP's major flaw:

Our party is called the Communist Party of Siam, but in truth our Party has only Chinese ... The basis by which we can change Siam comes down to a method by which we can bring Siamese into the Party. This is not a new problem. The same measure was discussed at our meeting last year ... where we decided that the first step was for members to study Siamese in preparation for contacting Siamese. It was decided to seek results in six months, but from that time to the present it has been a year and not a single branch has announced progress. ${ }^{54}$

Indigenizing communist parties in states in which the majority populations remained unreceptive to the communist message, or at least Sino-Vietnamese versions of it, would be a recurring problem in mainland Southeast Asia well into the postwar period..$^{55}$ The matter was even more complicated given that the internationalist projects of these Chinese and Vietnamese missionaries were simultaneously running up against emerging nationalist movements directed often against these two very ethnic groups, respectively. The Chinese encountered this problem in Malaya in the early 1930s and late 1940s, just as the Vietnamese did in Laos and Cambodia at the same junctures. ${ }^{56}$ But things got really complicated when Nguyen Ai Quoc, the good internationalist, had to explain away anti-Chinese Vietnamese nationalist riots in Haiphong in 1927 to the Comintern. ${ }^{57}$ 


\section{The Overland Vietnamese Origins of Laotian Radicalism}

If the overseas Chinese had introduced communism to the Southeast Asian port cities of Thailand and Malaya, the overland patterns of Vietnamese immigration to upper northeast Thailand led the Vietnamese to play the leading role in bringing radicalism to western Laotian urban centres. As in Thailand, Nguyen Ai Quoc presided over this transfer. In fact, during his first trip to Thailand in 1928-29, Quoc had ordered the expansion of the Youth League to Viet kieu communities concentrated in Laotian urban centres directly opposite his Thai bases. Quoc even made a brief trip to Laos in 1929 to evaluate the revolutionary potential there and to form liaisons with central Vietnam. ${ }^{58}$ Given that the Vietnamese constituted the majority of the urban population in Laos as well as its working class in the mines, on its road construction crews and in the Indochinese bureaucracy, ${ }^{59}$ it is hardly surprising that the Youth League's Laotian graft occurred along strictly ethnic Viet lines.

Returning to the Mekong in 1930, Quoc gave the personal order to transform the (few) Youth League organizations in Laos into communist cells (chi bo). According to Hoang Van Hoan, Quoc may well himself have formed the first 'Lao communist cell' (chi bo cong san Lao) in early 1930, separate from an Indochinese one, given that the ICP did not yet exist in early $1930 .{ }^{60}$ In any case, Vietnamese communists would form a Laotian Territorial Committee (Xu Uy Ai-Lao) on 9 September 1934, linked to the one Quoc had created in Udon, another in central Vietnam and to the ICP's headquarters now transferred to Macao under the Comintern and possibly the CCP's supervision. The tasks of this Laotian-based committee were to organize the Laotian section of the ICP (Dang bo) and to help rebuild the Annam section of the ICP following the French repression of 1930-31. As of 1934, though, Vietnamese communists had yet to recruit an ethnic Lao into their party apparatus. They would, however, convert two in 1935-36 (see below). ${ }^{61}$ The rest were all Vietnamese. 
If Chinese and Vietnamese shared the direction of the SCP between Bangkok (Hua qiao) and northeast Thailand (Viet kieu), Vietnamese radicals along the Mekong imported communism to Laos alone-not the native Lao or the Chinese. Why? First, the internal momentum of the Vietnamese revolutionary network outside Indochina, especially in northeast Thailand, had always been based on Viet kieu communities running from Bangkok to Nakhon Phanom-not on the ethnic Lao constituting the majority there. And as noted, the Hua qiao population remained relatively small along the Mekong and in Laos. ${ }^{62}$ Most were regional merchants anyway, with little interest in anti-bourgeois revolution. Second, coming from eastern Indochina, young, mainly urban Vietnamese radicals making their way to Thailand had few, if any, links to the Lao or Khmer peasantries prior to 1945 . Third, the urban nature of increasing Vietnamese immigration to western Laos in the 1920s and 1930s reinforced the stepping-stone nature of the Viet kieu pockets running both ways between northeastern Thailand and central Vietnamese provinces. ${ }^{63}$ Fourth, for cultural and political reasons which we can only evoke in passing here, Thai, Lao and Khmer youths did not always share the early interest of their Vietnamese neighbours for radicalism and Catholicism. Fifth, by the early 20th century, as banditry and slave trading across the highlands dropped off under the French, this route crossing the Annamese Cordillera tended to move more and more Vietnamese west. However, there were relatively fewer Laotians going east to work with the Vietnamese, and thereby come into contact with the revolutionary ideas and agitation shaking eastern Indochinese towns, mines and plantations in the 1930s (see below). Lastly, following closely on the ancient path outlined above, the construction of Colonial Route no. 9 actually increased Vietnamese immigration to the Mekong and provided more recruits for the ICP's Mekong organizations. ${ }^{64}$

Of course, mixed Viet-Lao marriages could have served as a conduit for bringing revolutionary-minded luuk khrung (métis) into the Vietnamese Youth League in the late 1920s. However, the patterns of predominantly male Vietnamese migration to Laos with the opening of Route 9 in the early 1920s would only 
start producing a few adult Lao-Viet métis revolutionaries in the mid-1940s (son of a Vietnamese bureaucrat, Kaysone Phomvihan is one example). ${ }^{65}$ More often than not, Vietnamese internationalists would recruit ethnic Lao and Khmer 'anticolonialists' inside French Indochina, from 'on high' inside the University of Hanoi or the Indochinese bureaucracy (Souphanouvong is a nice demonstration) or from 'down below' thanks to Laotian truck drivers crossing the Truong Son (Nouhak Phoumsavan comes to mind), Vietnamese-Cambodian métis fishermen moving up the Tonle Sap (Son Ngoc Minh is an example) or Cambodian prisoners serving time with Vietnamese militants at Poulo Condor (Pacheoun is a case in point). Rarely did this recruiting occur before 1945 .

The prewar dynamics of Vietnamese revolutionary immigration in Asia did create a number of postwar Vietnamese experts on Laos. By taking over long-standing patriotic Viet kieu communities in upper northeast Thailand, a generation of young Vietnamese radicals-perfectly fluent in Lao and at ease in Lao culture extending far into northeastern Thailand (Isan)-emerged within the most trusted circles of the ICP and within the very entourage of Nguyen Ai Quoc's Udon Thani/Canton classes. I am thinking of Nguyen Tai, Dao Viet Hung, Le Manh Trinh, Tran To Chan, Mai Van Quang, Hoang Van Hoan and Nguyen Cau Chinh. Most of these cadres would play key roles in building and running a Laotian revolutionary party, army and front from 1948. They did this from their prewar bases in upper northeast Thailand and upper central Vietnam (known better later as Lien Khu IV). This was even true before the Second World War. The evidence suggests that the first Lao communist, this enigmatic 'Khamseng', was born in Nakhon Phanom, recruited by Vietnamese communists in the Laotian mines of Phontiou and possibly taken by Hoang Van Hoan to China in 1935 under the name of 'Van'. There, Hoan left him with Le Thiet Hung for revolutionary training and possible dispatch to Moscow. ${ }^{66}$ In Thailand, these early Asian networks also manifested themselves later in revolutionary ways. The son of the niece of Dang Thuc Hua, known by his Thai name 'Thung', allegedly 'became a Thai citizen and 
some time in the early 1980s became deputy secretary or secretary general of the Thai communist party'. ${ }^{67}$

My point is that by the mid-1930s, Sino-Vietnamese-filtered Western radicalism had extended itself from southern China (Canton) to northeastern Thailand (Udon Thani), to make its way into Indochina's Laotian backdoor by way of Viet kieu immigrant networks linked to central Vietnam. Given the geography of these peninsular movements, in Laos and northeast Thailand the early canalisation of communism was an ethnically Vietnamese operation. In Bangkok, it was shared with the overseas Chinese. ${ }^{68}$ These 'implantations' were urban-based with little contact with the indigenous masses concentrated in the countryside (see below).

\section{The Poverty of Early Cambodian Radicalism}

To the southeast, another young Vietnamese radical named Tran Van Giau hoped to use the Viet kieu concentrated in Phnom Penh and southeastern Cambodia to form a parallel ICP Cambodian Territorial Committee (Xu Uy Cao Mien). Giau had first attempted this via the Transbassac Committee, subordinate to his semi-independent Southern Indochinese Federal Committee in 1934. Unlike his Nghe-Tinh counterparts, though, Giau had no bases among the Viet kieu in southeastern Thailand and chronic, internal dissension among southern Vietnamese communists may have diverted him from expanding his work up the Cambodian Mekong as his Asian-trained colleagues were doing across the Truong Son. Second, Giau was much more interested in organizing the workers in the cities than the peasants in the countryside; therefore, any interest he had in finding a 'Cambodian working class' had to focus, again, on the Viet kieu and Hua qiao majority proletariats in Phnom Penh or the Vietnamese coolies working the rubber plantations of eastern Cambodia. Third, the fact that Tran Van Giau, a young southerner trained in France and Moscow, was always in much closer contact with the French Communist Party's (FCP) Asian liaisons and agents hooked to Saigon would not have helped in Thailand, where the FCP had few, if any, links and Tran Van Giau was largely an unknown quantity to Quoc's Canton-Udon 
graduates. ${ }^{69}$ Indeed, Giau's Whampoa- and Youth Leaguetrained rival, Nguyen Van Tay (alias Nguyen Thanh Son), may have been the one dealing with Cambodia in the 1930s. Not without a parallel to Hoang Van Hoan's recruitment of 'Van', Nguyen Van Tay had first converted Son Ngoc Minh to the ICP's Cambodian cause in the 1930s. If Khamseng came from a Viet-Lao family in northeast Thailand, Son Ngoc Minh was a Viet-Khmer métis from the Cambodian minority of southern Vietnam, if not all Vietnamese. His real name was Pham Van Hua.

Indeed, the absence of ICP bases among the Viet kieu opposite western Cambodia, along the coast of the Gulf of Thailand and up the Tonle Sap is striking. Here one wonders whether Vietnamese revolutionaries ran up against stiff competition from their Catholic counterparts who, since the 17th century, had been firmly 'implanted' among Viet kieu communities running along the entire coast of the Gulf of Thailand from Rach Gia to Bangkok and straight up the Mekong River. Even in Laos, a French missionary warned of the competition priests would encounter in winning over converts among the poor Vietnamese coming to Laos:

Since the end of September [1928], agitators have arrived from Bangkok and Annam in order to exploit the patriotic feelings and the poverty, since the Annamese [Vietnamese] presently in Laos have come because they have nothing at home [in Vietnam]. There is nothing simpler [for the communists] than to build up their hopes by promising a quick return home, the sharing of wealth, equality and happiness for all, once the French are expelled. ${ }^{70}$

This double evangelization among the Viet kieu was real. We know, thanks to his 1930 report to the Comintern on the Viet kieu in Laos, that Nguyen Ai Quoc had lost 'over 1,000' Catholic supporters in Laos, when French priests threatened to refuse them communion (thong cong) if they joined Quoc's budding communist congregations. ${ }^{71}$ But our Catholic missionary had to admit that it was 'a real pain to have communist Christians' among his followers. The converse would be true, too. Interest- 
ingly, Nguyen Ai Quoc never went to the Thai-Cambodian border; he went further into the Nanyang.

\section{Ho Chi Minh and the 'Creation' of the Malaya Communist Party}

After having formed the VCP in Hong Kong in early 1930, a 'Lao communist cell' from Nakhon Phanom shortly thereafter, and the Siamese Communist Party in Bangkok in April 1930, Nguyen Ai Quoc took a boat to Singapore, where he attended, on behalf of the FEB, the Third Representative Conference of the South Seas Communist Party (see above) held in late April or early May 1930. Under Quoc's direction, the South Seas Communist Party was dismantled, as ordered by the Comintern, and rebaptized as a separate Malaya Communist Party (MCP). The MCP was also put in charge of fellow communist parties in Siam, British North Borneo and the Netherlands East Indies until the latter could stand on their own feet under the direction of the Far Eastern Bureau. 'The whole aim of this reorganization [of Nanyang communism]', a Special Branch report said, 'was to free the South Seas movement from the direct "central" control which was making it a purely Chinese movement'. Under the FEB, 'it was hoped that each individual state would progress along racial lines'. According to the Special Branch, the Comintern's idea in creating the FEB was to establish more direct contact with each regional country rather than relying entirely on the CCP's Nanyang networks running from Shanghai to Singapore, 'which hitherto had been the main instrument in the dissemination of communism in Eastern Colonial countries' (see above) ${ }^{72}$ Relying on captured SSCP archival documents, the British reported that the Comintern's failure to promote indigenous communism via CCP channels was one of the main reasons for the dispatch of Serge Lefranc (alias Ducroux) and the appropriation of 100,000 Straits dollars to reorganize the Nanyang parties 'along racial lines'. ${ }^{73}$ In his address to the 3rd Representative Conference of the SSCP, Quoc pointed out to his Chinese listeners the need to study the Malay language and to enlist ethnic Malay recruits in the party, all the more so since there were no Malay or Indians present at Quoc's 
'nationalist' transformation of the SSCP into the MCP for the 'internationalist cause'. ${ }^{74}$

The irony of all this could not have been lost on Quoc. Nowhere is this better seen than in the selection of the secretary general of the MCP. For if Nguyen Ai Quoc had lamented Chinese domination of Malay radicalism in 1930, chronic organizational and structural problems apparently left local communists with no choice but to allow an ethnic Vietnamese or Minh Huong, known by the pseudonym of 'Lai Teck', to take over the MCP.

Lai Teck had been a Comintern liaison chief in Hong Kong before arriving in Malaya in 1933 or 1934 and becoming the secretary general of the MCP in 1938. He held this office until $1947 .^{75}$ In August 1945, British military intelligence sources confirmed that Lai Teck, known secretly as 'Mr Wright' to the Allies during the war, was the former secretary general of the MCP prior to the Second World War and was still a member of the Central Committee after the war. The British identified him as an ethnic Vietnamese, as well as the MCP's 'most secret and revered personality. ... He is a shrewd and clever man, but no fanatic..$^{76}$ Lai Teck was apparently an informer passed by the French Surreté to the British Special Branch in 1934 or 1935. In 1947, he was de-masked and killed.

In view of our discussion so far, there was clearly a logic to this choice. Not only had the Vietnamese played the key role in forming their own party in Hong Kong in early 1930, but they had also helped create the SCP, a 'Lao communist cell', the MCP and would later form the Cambodian and Laotian Communist Parties. And even more important than this Sino-Vietnamese revolutionary intersection within the MCP in Singapore was the ability of so many Vietnamese communists to circulate in southern Chinese revolutionary networks, especially in Canton, Shanghai, Hong Kong and Singapore.

The problem was that delinking the early importation of mainland communism from its overseas Chinese and overland Vietnamese regional structures was much easier said than done. This was less because of ideological 'under-development' or 'weak nationalism' in the lands west of the Annamese Cordil- 
Christopher E. Goscha

lera than the long-standing mechanics of Sino-Vietnamese immigration across the peninsula; the indispensable, transnational role of Hua qiao and Viet kieu revolutionaries in the early (internationalist) 'stock' of the Comintern's (national) 'grafts' in the Nanyang; and their related faith in international communist salvation. This, in turn, might be analysed in terms of the early Chinese and Vietnamese position as the majority working classes in the urban centres of the mainland cities during the period of colonial modernization, especially in Laos and Cambodia, ${ }^{7}$ whereas the indigenous majority populations remained overwhelmingly concentrated in the countryside before 1945. There was thus little chance for these two currents to converge at the outset. Given the proletarian shift in the internationalist line in the late 1920s, the Comintern obviously had little choice but to turn to existing Vietnamese and Chinese majority working classes and ancient patterns of Sino-Vietnamese immigration to spread communism into peninsular Southeast Asian urban centres.

Vietnam, however, was in a unique position in these Nanyang revolutionary movements; for it was both an exporter of the Viet kieu workers and bureaucrats vital to the French colonial modernization of Laos and Cambodia in western Indochina and home itself to a large Hua qiao 'national minority' that was itself playing an important (and badly under-studied) modernizing role in colonial Vietnam. ${ }^{78}$ Given the Comintern's focus on urban workers, this may explain why Nguyen Ai Quoc reported to the FEB in early 1931 that of the 1,740 members of the ICP, there were 190 Chinese (11 per cent), and that of the 1,370 union workers there were 300 Chinese (18 per cent). Two Central Committee positions in the ICP had been reserved for Hua qiao communists in Indochina. ${ }^{79}$ If Vietnamese held important leadership positions in the Thai, Cambodian and Lao party sections, the regional nature of Hua qiao immigration in the Nanyang ensured that Chinese immigrant communists helped build communism in Vietnam, especially in the south where Chinese immigration had historically been concentrated. Two Chinese communists, Lam Lap Dao and A Duyen, held ranking positions in the Central Committee of the ICP during its shift to 
southern Vietnam after the break between communists and nationalists in southern China in the late 1920s and the French repression of Vietnamese revolutionaries in upper Vietnam from 1930. This Sino-Vietnamese revolutionary link was such that a dozen or so Hua qiao communists joined in the failed ICP Nam Ky uprising in 1940. Most of them were killed or arrested; some escaped to Thailand. ${ }^{80}$ But just as Vietnamese revolutionaries participated in the CCP's uprisings in Canton and Shanghai in 1927, so too these Chinese saw no nationalist contradiction in helping out against French colonialism in 1940 in southern Vietnam.

Yet viewed from a wider regional perspective, we might also note that there were no Lao revolutionary intellectuals crossing the Ai-Lao pass in 1930-31 to help out Vietnamese communists during the Yen Bay or Soviet Nghe-Tinh 'uprisings'. Nor did the ethnic Khmer 'revolutionaries' in southern Vietnam pick up arms during the Nam ky uprising in 1940. Indeed, Sino-Vietnamese success in evangelizing communism across the region remained weak west of the Annamese Cordillera. In September 1932, the MCP Central Committee admitted that it had 'not been able to organize other races and our activities have been confined to a section of the Chinese people'. As of 1934, 90 per cent of the $\mathrm{MCP}$ was Hainanese.$^{81}$ The Vietnamese importation of radicalism to Laos was running up against a similar form of indigenous disinterest as the Chinese in Malaya. Frustrated, a Vietnamese cadre conceded in 1934 that communism in Laos was 'nothing other than a sub-section of the Vietnamese Communist Party'. ${ }^{82}$ Two Thai analysts de gauche have even gone so far as to say that the Communist Party of Thailand 'was conceived from the womb of the CCP in 1942', the official national birthday of Thai communism. ${ }^{83}$ And if Western observers like to stress the 'French revolutionary connection' of Khmer intellectuals like Saloth Sar (Pol Pot) and Ieng Sary, it is worth recalling that the no. 2 in Les Khmers rouges, Nuon Chea, was a SinoCambodian from Battambang who had been 'formed' in Bangkok and was introduced to 'Asian radicalism' via the Communist Party of Thailand, itself created in 1930 by the ICP and the 
Christopher E. Goscha

CCP revolutionary missionaries. Early communism in peninsular Southeast Asia was a remarkably Sino-Vietnamese affair.

\section{Conclusion: Thinking about the 'Why' and Factoring in 'Culture'}

Again, this does not mean that Lao and Khmer 'intellectuals' were somehow less 'anti-colonialist', 'poor nationalists' or 'under-revolutionary'. However disappointing the absence of 'Cantons' or 'Yen Bays' in Laotian and Cambodian historiography may be for some, ${ }^{84}$ it might be more useful from a historical and methodological point of view to ask whether Lao and Khmer (and Malayan?) 'revolutionary' movements were flowing in other networks, with different geographies and separate goals. Moreover, it is not at all sure that Lao and Khmer 'intellectuals' remained inert during the colonial period, just waiting to be 'liberated' by the 'civilizing missions' of the Vietnamese, the Chinese, or even the French and the Thais for that matter. It all depends on where one looks. After all, during the colonial period, hundreds if not thousands of Lao and Khmer Theravada monks preferred to keep crossing that less than impermeable western Indochinese border in order to travel to Thailand. There they perfected their religious studies in scores of Thai Pagoda schools or entered into centres of higher learning for Pali and Theravada studies. It was largely because of the continued geo-cultural and religious pull of Thailand over 'western Indochina' and its Theravada minds that the French had to form their own Buddhist institutes in Laos and Cambodia. ${ }^{85}$ In this light, rather than forcing the Buddhist intellectual 'agitation' in Cambodia in the early 1940s or the 'uprisings' in southern Laos in 1936 to fit French, Russian, Western or Sino-Vietnamese revolutionary models of what is to come in the future, 86 we might want to ask how it was geographically, historically and culturally different. The teleologies of 'French colonial' and 'Vietnamese communist' historiographies of Indochina should not prevent us from picking up on deeper and wider historical connections. ${ }^{87}$ 
While I certainly admit that Euro-Asian police repression most certainly complicated the Comintern's internationalist success rate before the Second World War, these internal Vietnamese and Chinese documents reveal nevertheless that local cultural factors will also have to be taken into consideration in studies of the limitations of the Sino-Vietnamese diffusion of communism to the lands west of the Annamese Cordillera. Indeed, judging from the preponderant role played by the Chinese and Vietnamese in the early entry of communism to peninsular Southeast Asia, future research might explore in greater detail why communism failed to take form among the indigenous populations and elites of Laos, Cambodia, Thailand and Malaya before the Second World War and, yes, even thereafter. ${ }^{88}$

Again, I am not saying that one had to be Confucian to be communist. Nor am I denying any Lao or Khmer the right to become a revolutionary or a communist or anything else they want to be. I am, however, suggesting that rather than analysing 'Asian' communists and communisms as if they are all one and the same, it might be worthwhile to think about how they differed. And if we should be careful not to force the link between Confucianism and communism in studying Vietnamese radicalism, we might also think twice about accepting uncritically the view that Cambodians and Laotians adopted Western radicalism in the same ways as the Vietnamese, just because Cambodian or Laotian 'parties' were eventually formed, because they all shared an oppressive 'Indochinese' colonial past, fought the French and American 'imperialists' or studied a little Marxism in France. It was surely more complicated than that once things had to work themselves out on the ground. ${ }^{89}$ After all, even after forming 'proto-Communist' parties for Laos and Cambodia in 1950-51, Indochinese communism remained an undeniably ethnic Vietnamese affair. In 1951, for example, Vietnamese communists conceded that ethnic Khmers constituted only 8.4 per cent of the Cambodian 'party' and the Laotians only made up 3.8 per cent of the Lao section. ${ }^{90}$ Did Cambodians and Laotians -revolutionaries or not-truly, or at least always, conceive the ideas of power, revolution, nationalism, colonialism and communism in the same ways as Vietnamese and 
Christopher E. Goscha

Chinese intellectual revolutionaries, let alone their Western counterparts? Perhaps not. ${ }^{91}$

Methodologically, we might get at these complex questions by placing them within a wider regional perspective, such as the one outlined above, and by focusing on the people and the routes by which communism flowed into the peninsula. Such a geographically grounded debut might then better guide us in the exploration of the complicated cultural world(s) these SinoVietnamese missionaries of revolution encountered when they moved into the western half of peninsular 'Indochina', especially the Theravada lands located hardly 150 kilometres west of Hue. By combining the how and the why in this way we might grasp a little better the frustration of a ranking Vietnamese communist cadre charged with creating a Cambodian revolutionary party in 1950. In his mind, the major threat to the 'Cambodian Revolution' (Cach mang Cao-Mien) in 1950 came less from French imperialism than from a recurrent absence of Cambodian interest in Sino-Vietnamese-inspired revolution. Echoing prewar reports of failed conversions in Laos and Malaya, this ranking Vietnamese cadre in the field did not mince his words in 1950:

The Cambodian revolution must be the work of the Cambodians. If the Cambodians don't wake up, if their cadres don't know how to work, then it doesn't matter how many millions of [Vietnamese] cadres or thousands of tons of weapons and money we send them, it still won't do anything to help the Cambodian revolution. 92

Indeed, it was from this point in time (and not 1945) that Vietnamese communists accelerated their efforts to propagate (truyen $b a$ ) communism among the indigenous peoples of Laos and Cambodia. Frustrated, Vietnamese 'cadres' had to turn to recruiting monks, to incorporating Buddhist icons and symbols into their propaganda and even to taking up the religious garb in a bid to convert the masses more effectively. Like French and Vietnamese Catholic missionaries long before them, the results were very limited..$^{93}$ But this was not just the case for these Vietnamese modernists; it was also true for those 'Western' Khmer intellectuals returning from France at this same conjunc- 
ture, determined to remake Cambodian society even more radically than the Vietnamese. Indeed, things got really nasty when these French-trained Khmer intellectuals tried to uproot Cambodian communism from its Vietnamese networks along profoundly national lines, ${ }^{94}$ to remould peasant and Buddhist Cambodia in revolutionary ways not without echoes in an Angkorian past; and all this as Sino-Vietnamese internationalism came tumbling down from on high.

Admittedly, these matters, above all the why, deserve much more serious research than this. In this paper, I have tried to outline one part of a methodologically complicated question. In dealing with the how, I have suggested the possible merits of a regional approach running over a longer span of time than we are normally accustomed to; one that brings geography into the picture, allows for cultural and demographical factors, underscores possible temporal synchronisms and gets us beyond the straitjacket of fiercely nationalist and colonial historiographies without necessarily sacrificing the événement. ${ }^{95}$ I have also tried to suggest the possible merits of factoring Asian variables into our analytical framework of communism in terms of how they worked themselves out on the ground and not just in revolutionary heads. The West was certainly important; but we would have an incomplete picture if we did not consider how these ideas were diffused geographically, filtered socially and adapted culturally as they moved their way through Asia. My aim is not to downgrade Western theories or advocate cultural relativism, let alone push 'Asian values' in these days of (troubled) Asian regional identity; but I think that this part of the world is just too complicated to leave the Asian regional connections out. Vietnamese communism, like its Catholic predecessor, is no exception. What remains to be examined now is how the 'evangelical message' was adopted or rejected by the local people on the ground and why.

Christopher E. Goscha, is the author of Vietnam or Indochina? (NIAS, 1995) and Thailand and the Southeast Asian Networks of the Vietnamese Revolution (Curzon, 1999), and recently submitted his doctoral thesis at the Sorbonne on the Asian Context of the 
Christopher E. Goscha

Franco-Vietnamese War-Networks, Relations and Economy (194554). Goscha, who is American, teaches History and Geography at the International School of Paris. Contact address: Groupe d'Etudes sur le Viet-Nam Contemporain, SciencesPo, 27, rue Saint-Guillaume, 75007 Paris, France.

E-mail: gr.vietnam@sciences-po.fr

\section{Notes}

1. On the 'total failure' of Catholicism in Siam and its 'relative success' in Tonkin in the 17th and 18th centuries, see: Alain Forest, Les missionnaires français au Tonkin et au Siam (XVIIe-XVIIIe siècles): Analyse comparée d'un relatif succès et d'un total échec, vols I-III. Paris: L'Harmattan, 1998.

2. A Vietnamese geographer used the word 'Southeast Asia' before the Second World War. See: Nguyen Van Que, Histoire des pays de l'Union indochinoise. Saigon: Imprimerie Nguyen Khac, 1932, the cover.

3. François Ponchaud, La cathédrale de la rizière: 450 ans d'histoire de l'Église au Cambodge. Paris: Fayard, 1990, pp. 43-44, 87-88, 101; Eric Guerassimoff, 'Les gangzhu du Johor. Souvenirs d'un missionnaire français en Malaisie (1859-1870)', Etudes Chinoises, 1, (XVI), (Spring 1997): 101-140; and Christopher E. Goscha, 'La présence vietnamienne au Siam du 17e au 19e siècle: Vers une perspective péninsulaire', in Nguyen The Anh and Alain Forest (eds), Guerre et Paix en Asie du Sud-est. Paris: Editions L'Harmattan, 1998, pp. 211-243.

4. Comparison is difficult given the different historical, cultural and diplomatic contexts and conjunctures. For one thing, many Vietnamese in Thailand and Vietnam converted to communism as a way of freeing their country from colonial domination, unconcerned by theoretical questions of a workers' paradise. Vietnamese who became Catholic in the 17 th century were obviously not doing so for nationalist reasons, but for sociocultural ones. In contrast to Theravada Buddhist Siam, there were over 100,000 Vietnamese Catholics in Vietnam by the late 17th century. Second, it is by no means sure that the Viet kieu or the Vietnamese in Vietnam ever converted en masse to communism. There were only 5,000 communists in 1945. There were, however, many voluntary village conversions to Catholicism among the Viet kieu in Thailand, Cambodia and Vietnam. Third, Vietnamese were not simply choosing between Catholicism and communism; many were Buddhist, Cao Dai, Hoa Hao, etc. Lastly, many Vietnamese in Thailand (and Vietnam) joined the Party, because not to do so would have invited repression or sidelining from the communist leadership. On communism and Christianity in China, see: G. 
Pontmarin, 'La conjoncture missionnaire en Chine', Sud-Est, 18, (December 1950): 15-19.

5. On Indonesian communism, see Ruth T. McVey, The Rise of Indonesian Communism. Ithaca: Cornell University Press, 1965. On Burma, see Robert H. Taylor, 'The Burmese Communist Movement and its Indian Connection: Formation and Factionalism'. Journal of Southeast Asian Studies, XIV (1) (March 1983): 95-108.

6. Huynh Kim Khanh, Vietnamese Communism, 1925-1945. Ithaca: Cornell University Press, 1982 and Stein Tønnesson, The Vietnamese Revolution of 1945. London: Sage, 1991.

7. Two notable exceptions are: MacAlister Brown and Joseph J. Zasloff, Apprentice Revolutionaries: The Communist Movement in Laos, 1930-1988.. Stanford: Hoover Institution Press, 1986 and Geoffrey Gunn, Political Struggles in Laos (1930-1954): Vietnamese Communist Power and the Lao Struggle for National Independence. Bangkok: Editions Duang Kamol, 1988.

8. The value of this approach has long been argued by the late Denys Lombard, 'Une autre "Méditerranée" dans le Sud-Est asiatique', Hérodote, 88, (1st trimester 1998): 184-193; his Le carrefour javanais: Essai d'histoire globale. Paris: Editions de l'Ecole des Hautes Etudes en Sciences Sociales, 1990; and Jacques Népôte, 'Pour une reconstruction de l'histoire du Cambodge'. ASEMI, XV (1-4), (1984): 69-101.

9. Claudine Salmon, 'The Contribution of the Chinese to the Development of Southeast Asia: A New Appraisal'. Journal of Southeast Asian Studies, XII (1) (March 1981): 260-275.

10. Chingho A. Chen, 'Mac Thien Tu and Phrayataksin: A Survey on Their Political Stand, Conflicts and Background'. Proceedings of the Seventh IAHA Conference, Bangkok: Chulalongkorn University Press, 1979; Nguyen The Anh, 'L'immigration chinoise et la colonisation du delta du Mékong'. The Vietnam Review, 1 (Autumn-Winter 1996): 157; and Charnvit Kasetsiri, The Rise of Ayudhya, Bangkok: Duang Kamol, 1976.

11. Pierre Trolliet, La diaspora chinoise. Paris: PUF, 1994, pp. 11-23; Nguyen The Anh, 'Secret Societies: Some Reflections on the Court of Hue and the Government of Cochinchina on the Eve of Tu Duc's Death (1882-1883)'. Asian Affairs, IX, part 2, (June 1978): 179-185.

12. Yong Ch'ing Fatt and R. B. McKenna, The Kuomingtang Movement in British Malaya. Singapore: Singapore University Press, 1990, p. 13, table I. My thanks to Eric Guerassimoff for a copy of this article.

13. Denys Lombard, 'Une autre 'Méditerranée' dans le Sud-Est asiatique', p. 185; Georges Boudarel, 'Phan Boi Chau et la société vietnamienne de son temps'. France-Asie, XXIII (4) (1969): 422-433.

14. For more details, see Geoff Wade, A Maritime Route in the Vietnamese Text Xiem-la-quoc Lo-Trinh Tap-luc (1810). Paper presented at the Second International Euro-Japanese Seminar on Trade and Navigation in Southeast 
Christopher E. Goscha

Asia, Sophia University, October 1997; Goscha, 'La présence vietnamienne au Siam', pp. 211-243.

15. According to William Skinner, in 1904 Chinese immigrants to northeast Thailand numbered around 6,950-only 1.7 per cent of the total number of Chinese immigrants in Thailand, whereas the Chinese in lower Thailand accounted for 59.8 per cent of the total. G. W. Skinner, Chinese Society in Thailand: An Analytical History. Ithaca: Cornell University Press, 1957, table 4, p. 74. Few of the Chinese in the northeast had made it into Laos by the early 20 th century. See below.

16. Goscha, 'La présence vietnamienne au Siam', pp. 211-243.

17. Unsurprisingly, early Vietnamese 'anti-colonial diplomacy' in Asia first tried to take advantage of any pre-existing, 'pre-colonial' Asian connections. Thinking of Thailand, Phan Dinh Phung instructed his partisans to exploit possible Thai court contacts stemming from the marriage of one of Gia Long's sisters to Rama I. In 1906, Cuong De fled to Canton where his sister sheltered him. She had married a Chinese man from Canton, apparently influential enough to be accepted into Vietnamese royalty. Similarly, Prince Cuong De would marry into the Japanese royal family, which worried the ruling powers in Vietnam well into the 1940s.

18. A very nice example of this link is Cuong De's memoirs, as recorded by Tung Lam, Cuoc doi Cach Mang Cuong De [The Revolutionary Life of Cuong De]. Saigon: Ton That Le, 1957, pp. 44-54.

19. Yen Ching Hwang, The Overseas Chinese and the 1911 Revolution, with Special Reference to Singapore and Malaya. Kuala Lumpur: Oxford University Press, 1976, pp. 304-305.

20. 'Traduction d'une note signée par l'Annamite Phan Boi Chau et saisie à Hangtchéou, A mes compatriotes au Siam', undated, in carton [hereafter, c.] 353, fonds Service de Protection du Corps Expéditionnaire [hereafter, $\mathrm{SPCE}$ ], Centre des Archives d'Outre-Mer [hereafter, CAOM, Aix-enProvence].

21. Furuta Motoo, "The Vietnamese Political Movement in Thailand: Legacy of the Dong-du Movement'. In Vinh Sinh (ed.), Phan Boi Chau and the Dong-Du Movement. New Haven: The Lac-Viet Series, no. 8, 1988.

22..Christopher E. Goscha, 'Entremêlements sino-vietnamiens: Reflexions sur le Sud de la Chine et la revolution vietnamienne entre les-deux-guerres'. Approches-Asie, 16 (1999): 81-108. Other 'revolutionary routes' went from Haiphong to Canton, Lao Cai to Kunming and Cao Bang to Nanning.

23. Actually, since the 7th century AD, Nestorian Christian missionaries had arrived in China by land routes.

24. C. Martin Wilbur and Julie Lien-ying How, Missionaries of Revolution: Soviet Advisors and Nationalist China, 1920-1927. Cambridge, MA: Harvard. University Press, 1989. 
25. See also Ralph Smith, 'The Foundation of the Indochinese Communist Party, 1929-1930'. Modern Asian Studies, 32, (4) (1998): 769-805; Georges Boudarel, 'L'extrême-gauche asiatique et le mouvement national vietnamien (1905-1925)'. In Pierre Brocheux (ed.), Histoire de l'Asie du Sudest: Révoltes, Réformes, Révolutions. Lille: Presse Universitaires de Lille, 1981, pp. 165-192.

26. 'Rapport sur le Tonkin, l'Annam et la Cochinchine', Moscow 1924, unsigned. In Alain Ruscio (ed.), Ho Chi Minh: Textes (1919-1969). Paris: L'Harmattan, 1990, pp. 69-74.

27. Like Dang Thuc Hua, Ho Hoc Lam was an early member of the Dong Du. If Hua went to Siam, Lam immigrated to southern China in 1910 and later studied in the same military class as Chiang Kaishek. The latter offered him a position on his general staff in the early 1930s. Lam accepted and became a colonel in the GMD; but he kept working for the Vietnamese patriotic cause. He was the father-in-law of Le Thiet Hung, the uncle of Ho Tung Mau and deeply trusted by (if not related to) Nguyen Ai Quoc. Hoang Van Hoan came from the same village as Lam. Similarly, Quoc's earliest allies, Ho Tung Mau and Le Hong Son, were initially the confidants of Phan Boi Chau and Prince Cuong De, respectively.

28. See: Goscha, 'Entremêlements sino-vietnamiens', pp. 81-108.

29. Ibid. Among Quoc's Canton students from central and northern Vietnam, we can identify Nguyen Son (Vu Nguyen Bac), Le Hong Phong, Le Manh Trinh, Tran To Chan, Nguyen Tai, Hoang Van Hoan, Phung Chi Kien, Le Thiet Hung, Vu Hong Anh and Ho Tung Mau among many others. For those from Thailand, we can note Ly Tu Trong, Hoang Sam and Ngo Chinh Hoc and Quoc. An important Cochinchinese exception is Nguyen Van Long.

30. Goscha, 'Entremêlements sino-vietnamiens'.

31. Tbid. More than a dozen Vietnamese participated in the CCP-led Canton uprising of late 1927. Ho Tung Mau, Cao Hong Lanh and Le Hong Son were all CCP members.

32. I am not saying that all Vietnamese and Chinese communists fled to Southeast Asia. Several Vietnamese followed the CCP faction led by Mao Zedong further into China. Some went to Shanghai where the CCP was still operating. Some went to Moscow; others were arrested. And a few were executed.

33. Cheah Boon Kheng, From PKI to the Comintern, 1924-1941: The Apprenticeship of the Malaya Communist Party. Ithaca: Southeast Asia Program, 1992, p. 14; Yong Ch'ing Fatt, Chinese Leadership and Power in Colonial Singapore. Singapore: Times Academic Press, 1994 (2nd edition), pp. 233-234.

34. The CCP appeared in southern Vietnam in 1927, when Ho Pe Siang tried unsuccessfully to form the Association of Overseas Revolutionary Parti- 
Christopher E. Goscha

sans in Saigon. In 1932, an effort was made by a colleague to revive it in another form, but to no avail. 'Note sur les activités chinoises du Sud Vietnam', dated April 1952, p. 27, c. 10H659, SHAT; 'Note sur les activités politiques chinoises en Indochine', September 1946, d. Communistes chinois, 5, c. 104, fonds Conseiller Diplomatique, CAOM.

35. William Duiker, [Biography of Ho Chi Minh], manuscript, p. 3. My thanks to Professor Duiker for allowing me to consult the manuscript of his forthcoming biography of Ho Chi Minh.

36. The centre of gravity of the Vietnamese communist leadership would not really shift back to southern China until around 1940, following the French destruction of the southern ICP apparatus; the Japanese occupation of all mainland Southeast Asia (including Thailand), and the. renewed alliance between the GMD and CCP in southern China in the war against the Japanese. Nguyen Ai Quoc returned to Kunming around 1938 to begin rebuilding the ICP's Sino-Vietnamese networks, but this time near Cao Bang, the northern overland gateway to Tonkin. Ho Hoc Lam was there to help, again.

37. 'La fusion des associations anti-françaises en Indochine et l'action déterminante de Nguyen Ai Quoc dans la création du Parti National Communiste Annamite', envoi no. 284, SG, 19 January 1931, signed by Marty, d. Unification des sociétés secrètes sous l'égide de la IIIè Internationale, c. 367, SPCE, CAOM.

38. And where official Vietnamese and Thai Communist historians fall simultaneously silent. Nopporn Suwanpanich and Kraisak Choonhavan, The Communist Party of Thailand and Conflict in Indochina. The Hague: Institute of Social Studies, 1980, pp. 12-13.

39. Police Journal, Straits Settlements, no. 5 of 1931, 15 May 1931.

40. See: Sophie-Quinn-Judge, 'Ho Chi Minh: New Perspectives from the Comintern Files'. Viet Nam: Sources et Approches, Aix-en-Provence, Publications de l'Université de Provence, 1996, pp. 172-187.

41. While serving on Chiang Kaishek's General Staff, Ho Hoc Lam worked as a mole for the CCP and the ICP. See Ho Khai Dai, 'Ho Hoc Lam va Di Tac Quan Su'. Tap Chi Xua va Nay, 49 (March 1998): 9-10. Ho Hoc Lam's son-inlaw, Le Thiet Hung, asked him to do so on behalf of Nguyen Ai Quoc.

42. Furuta Motoo, 'The Vietnamese Political Movement in Thailand', p. 158.

43. This plan had been presented to Comintern representatives in Hong Kong by the Chinese delegate of the 'special branch of the CCP in Singapore'. Duong Hac Dinh, 'Schéma des liaisons possibles entre différents groupements communistes d'Extrême-Orient', in c. 365, SPCE, CAOM.

44. William Duiker, [Biography of Ho Chi Minh], manuscript, chapter VI, p. 2 and Duong Hac Dinh, 'Schéma des liaisons de la III $^{\circ}$ Internationale 
communiste avec les divers partis nationaux ... (Projet de Nguyen Ai Quoc et des délégués)', c. 365, SPCE, CAOM.

45. Furuta Motoo, 'Vietnamese Political Movements in Thailand', pp. 159160; Nguyen Ai Quoc, 'Bao cao gui Quoc te Cong san' [Report to the Comintern], dated 18 February 1930, in Ho Chi Minh Toan Tap, vol. 3, Hanoi: NXB Chinh Tri Quoc Gia, 1995, pp. 15-16.

46. Nguyen Ai Quoc wrote: 'I propose that the VCP be directed from Shanghai by way of Hong Kong'.

47. Furuta Motoo, 'Vietnamese Political Movements in Thailand', pp. 159-160 and Nguyen Ai Quoc, 'Bao cao gui Quoc te Cong san', dated 18 February 1930 , p. 16.

48. Hoang Van Hoan, Giot Nuoc trong Bien Ca (Hoi Ky Cach Mang) [A Drop in the Ocean, Revolutionary Memoirs]. Beijing: NXB Tin Viet Nam, 1986, p. 60; 'La fusion des associations anti-françaises en Indochine'; and Personal dossier on Nguyen Ai Quoc in d. Nguyen Ai Quoc: Documents emportés par M. Nevon [sic, Néron] lors de sa mission à Hong Kong, c. 364, SPCE, CAOM.

49. Xuan An, 'Dong Chi Tran To Chan' [Comarade Tran To Chan]. Tap Chi Lich Su Dang, 5 (1994): 58.

50. Hoang Van Hoan, Giot Nuoc, pp. 61-63.

51. Cheah Boon Kheng, From the PKI, pp. 32, 61, n. 39; Dennis J. Duncanson, 'Ho-chi-Minh in Hong Kong, 1931-1932'. The China Quarterly, 57 (January/March 1974): 87. A certain Fu Tai-keng had been trained in Moscow and had served as a secretary to Borodin in Canton in 1927. Yang Ch'ing Fatt, Chinese Leadership and Power in Colonial Singapore, p. 239.

52. 'Siamese Executive Committee to the Malaya Communist Party', 20 September 1932, k. t. 39/13-30, Communists 2473-2480 [1930-1937], Box 2, Thai National Archives, Bangkok and 'Annual Report, 1932', p. 11, FO371/17178/F1558/1558/40, Public Records Office [hereafter, PRO].

53. Hoang Van Hoan, Giot Nuoc, p. 93.

54. 'Party Monthly Paper', 15 November 1932 in 'Communists-Banishment of Chinese Citizens, 2475-2476 [1932-1933]', k.t. 39/26, Thai National Archives.

55. Christopher E. Goscha, Le contexte asiatique de la guerre franco-vietnamienne: réseaux, relations, économie. Paris, thesis, Ecole Pratique des Hautes Etudes, 2000, section indochinoise.

56. Vietnamese communists along the Mekong in the 1930s bemoaned the effects of Prince Phetsarath's nationalist movement against increased Vietnamese immigration to Laos and related Vietnamese dreams of building an Indochinese Federation. See 'Traduction d'une brochure de 9 pages intitulée "Rapports. Conférence des Représentants du Laos" du 7 au 9 septembre $1934^{\prime}$, pp. 13, 17, c. 54, SLOTFOM, III, CAOM; Van Kien Dang (1930-1945), Hanoi: Ban Nghien Cuu Lich Su Dang Trung Uong 
Xuat Ban, 1977, vol. I, p. 476; and Christopher E. Goscha, 'L'Indochine repensée par les Indochinois'. Revue Française d'Histoire d'Outre-Mer, 82 (309) (1995): 421-453.

57. N.K. [Nguyen Ai Quoc], 'La domination française en Indochine'. Inprekor, 104, (15 October 1927), in Ho Chi Minh Toan Tap, vol. 2, pp. 249-251.

58. Nguyen Tai, 'Nho lai Ngay dua Bac Ho tu Thai Lan sang Gay Dung Co So Cach Mang o Lao' [Remembering the Day I Escorted Uncle Ho from Thailand to Promote the Building of Revolutionary Bases in Laos]. Tap Chi Cong San, 12 (December 1986): 80-82; Hoang Van Hoan, Giot Nuoc, p. 59.

59. Pierre-Bernard Lafont, 'Aperçu sur l'évolution urbaine au Laos'. In Péninsule indochinoise: études urbaines, Paris: L'Harmattan, 1991, pp. 109110.

60. Hoang Van Hoan, Giot Nuoc, p. 63.

61. Brown, MacAlister and Zasloff, Joseph J. 1986, Apprentice Revolutionaries: The Communist Movement in Laos, 1930-1985. Standford: Hoover Institution Press, p. 15; Gunn, Political Struggles in Laos, pp. 43-44, 46.

62. Tsai Maw-Kuey, Les Chinois au Sud-Vietnam. Paris: Bibliothèque Nationale, 1968, p. 41, Table III. The Chinese population dropped from 7,000 in 1921 to 3,000 in 1931.

63. In 1943, the Vietnamese formed $85 \%$ of the population of Thakhek, $72.5 \%$ in Savannakhet, 63\% in Pakse and 53\% in Vientiane. Lafont, 'Aperçu', pp. 109-110.

64. 'Note périodique no. 31 de la Direction de la Sûreté Générale Indochinoise (2e trimestre 1934)', p. 27, c. 52, SLOTFOM, III, CAOM.

65. And not all Lao-Viet luuk khrung were destined to become communists, as in the case of Katay Don Sasorith. He was the son of a wealthy Vietnamese merchant, who, like Kaysone Phomvihan, studied in Hanoi. Katay was one of Laos' first modern nationalists during the Second World War, a key leader of the Lao Issara and a minister in subsequent independent governments. Katay refused all collaboration with Vietnamese communists.

66. Hoang Van Hoan, Giot Nuoc, pp. 89, 117-118 and 'Parti communiste [laotien], Comité central N.LH.S', 10 October 1958 and 1 February 1958, d. 75, c. G14-7, Laos, 1945-65, fonds Jean Deuve, Caen Memorial, France. Hoan refers to this person as 'Van' and as a communist from Thailand, whereas the French source speaks of 'Khamseng'. Both sources, however, confirm that this person was entrusted to future General Le Thiet Hung in 1935, leading me to hypothesize that this 'Van' was probably 'Khamseng', who joined the ICP in 1936. This French source claims that General Hung was in charge of recruiting the first Lao communists in 1945. General Hung ran LKIV in late 1945. 
67. The information on 'Thung' comes from a former Vietnamese official who lived in Thailand after the Second World War and who has insisted on absolute anonymity. This claim is unconfirmed. Steve Heder has kindly informed me that CPT sources in Thailand have confirmed to him that they have heard of such claims. It is known that Charoen Wan-ngam (First Secretary of the CPT in 1980), Prasit Thiensiri (Politburo member in 1980), and Thong Jamsri (Politburo member and deputy commander of the CPT army in 1980) 'were apparently among those trained by the Vietnamese émigrés in the early 1930s'. Suwanpanich and Choonhavan, 'The Communist Party of Thailand', pp. 14-15.

68. Nguyen Ai Quoc, 'Bao cao gui Quoc te Cong san' [Report to the Comin tern], dated 18 February 1930.

69. However, Tran Van Giau may have collaborated with (Moscow-trained?) Chinese internationalists in Shanghai, some of whom were forced into southern Vietnam following the fall of Shanghai to the Japanese in mid1937. Tran Van Giau speaks no Asian language other than his native Vietnamese.

70. Les Missions Catholiques, 3074, (16 November 1928), p. 523. My thanks to Frank Proschan for this reference.

71. Nguyen Ai Quoc, 'Bao cao gui Quoc te Cong san', dated 18 February 1930 , pp. 11-12.

72. Straits Settlements Police, Police Intelligence Journal, supplement no. 4 to issue no. 11 of 31 November 1932, 'Communism in Malaya in 1931 and 1932', p. 2, Special Branch, Singapore, 23 November 1932, c. 65560, GG, CAOM.

73. 'Communism in Malaya in 1931 \& 1932', pp. 1, 5-6 and 'Communist Propaganda among Malay and Indians', Supplement no. 12 to no. 10, dated 31-10-1934, Special Branch, c. 65560, GG, CAOM.

74. Yong Ch'ing Fatt, Chinese Leadership and Power in Colonial Singapore, $\mathrm{p}$. 236.

75. Yoji Akashi, 'Lai Teck, Secretary General of the Malayan Communist Party, 1939-1947'. Journal of the South Seas Society, 49, (1994): 57-102; C. F. Yong, The Origins of Malayan Communism. Singapore: South Seas Society, 1997, pp. 128-151; Cheah Boon Kheng, From PKI, pp. 25-28, for more details on this person. Lai Teck's real Vietnamese name was possibly Huynh Kim Ngoc. I am grateful to Judy Stowe for providing me with this information.

76. HQ Force 136 to Kandy, 'Memorandum by Head of Malaya Country Section, Force 136, on Resistance Forces in Malaya on the Eve of the Japanese Capitulation', 21 August 1945, WO203/5767, PRO.

77. During the 'colonial period', increasing numbers of Chinese, Vietnamese and Indian immigrants played key roles in the 'modernization' of local bureaucracies, industries and cities in Malaya and Vietnam, western 
Christopher E. Goscha

Indochina and Burma. Indian and Bengali emigrants apparently played an important role in introducing Communism to Burma from India, not Canton. Taylor, 'The Burmese Communist Movement and its Indian Connection', pp. 95-108.

78. The Chinese population in Cochinchina increased from 156,000 in 1921 to 205,000 in 1931. Tsai Maw-Kuey, Les Chinois au Sud-Vietnam, p. 41, Table III.

79. Translated and reproduced in 'Gouverneur général de' l'Indochine à Ministre des Colonies', no. 2758/SG, Hanoi, 11 August 1932, d. Bureau d'Extrême-Orient, c. 127, SLOTFOM, III, CAOM and Nguyen Ai Quoc, 'Bao cao gui Quoc te Cong san', dated 18 February 1930.

80. H.D., 'Phong trao nguoi Hoa o Do Thi Saigon', in Mua thu roi, ngay ham $b a$, volume II, $3^{\text {rd }}$ section, Hanoi, NXB Chinh Tri Quoc Gia, 1996, pp. 468469; 'Note sur les activités chinoises au Sud Vietnam (avril 1952)', p. 27, c. 10H659, SHAT; and Secteur Saigon-Cholon, S/Secteur Cholon, no. 1339/SSC/S, 'Rapport sur l'activité des Chinois à Cholon', d. BR58, c. 10H4358, SHAT.

81. 'A Review of the Condition of the Malaya Communist Party in Malaya during the Years 1932 and 1933: Compiled by Mr. J. C. Barry on the original records of the Party's representative Conferences held in 1932 and 1933', Special Branch, Straits Settlements, 30 June 1934, pp. 1-2, in c. 65560, GGI, CAOM.

82. 'Résolutions prises par la Conférence régionale des Représentants du Laos du 6 au 9 septembre 1934', c. 54, SLOTFOM, III, CAOM.

83. Suwanpanich and Choonhavan, 'The Communist Party of Thailand', $p$. 18. The change in the birthday of Thai communism to 1942 reminds us of a similar etymological move by 'Kampuchean' nationalist communists.

84. Christopher E. Goscha, Indochinese Past Perfect: Communist Vietnam's Revo -lutionary Historiography on Laos (1975-95). Paper delivered at the 7th International Conference on Thai Studies, 4-8 July 1999, Amsterdam, The Netherlands, forthcoming.

85. See the report of Suzanne Karpelès on the reasons for the creation of the Buddhist Institute in Laos in 1931. Bulletin de l'Ecole Française d'Extrême-Orient, XXXI, (1-2), (January-February 1931): 331-335.

86. For a wider view on Western revolutionary historiography, see: François Furet, The Passing of an Illusion. Chicago: The University of Chicago Press, 1999.

87. Looking to southern Vietnam, though, one might also ask why several leading Khmer nationalists who came to the fore in the early 1940s were from the Khmer Krom (ethnic Khmer) community in southern Vietnam. Son Ngoc Thanh certainly comes to mind. So do the 'revolutionaries' Tou Samouth and possibly even Son Ngoc Minh. 
88. See in particular: Suwanpanich and Choonhavan, 'The Communist Party of Thailand', pp. 16-25.

89. And just because Pol Pot knew a little French does not necessarily mean that he grasped the whole corpus of Marxism-Leninism, let alone understood what had gone into the making of 'Maoism'.

90. On the regional nature of the Vietnamese creation of Cambodian and Laotian revolutionary parties in 1950-51, see: Goscha, 'Le contexte asiatique', section indochinoise.

91. Can one, methodologically, put Laotian communism in the same geographical basket with the Chinese and Vietnamese varieties, without taking into account the massive role played by the Vietnamese in exporting and building communism in Laos? The Livre Noir does. See: Stéphane Courtois et al., Le Livre Noir du Communisme. Paris: Robert Laffont, 1997.

92. Ban Can Su Cao-Mien, Ban Thuong Vu, so [no.] 110/CS-TU, 'De muc: Ke-hoach hoat dong o moi vung tren lanh tho Cao Mien' [Object: Operational Plan for all Zones in the Territory of Cambodia], signed Dien Nam, dated 18 July 1950, d. Organisation du Front du Cambodge, c. 10H4121, Service Historique de l'Armée de Terre, Vincennes [SHAT].

93. Goscha, 'Le contexte asiatique', section indochinoise.

94. And Pol Pot did not introduce Maoism to Cambodia. Son Ngoc Minh first did this in 1950, and thanks to the Vietnamese cadres schools in which he was trained in Rach Gia and Ha Tien. Moreover, Maoism entered Cambodia in Vietnamese translation. See: Goscha, 'Le contexte asiatique', section indochinoise.

95. See above all Denys Lombard, 'Networks and Synchronisms in Southeast Asian History'. Journal of Southeast Asian History, 26, (1) (March 1996): 10-16. 